\title{
An Investigation of the Effect of Toughness and Brittleness Indexes on Ampere Consumption and Wear Rate of a Circular Diamond Saw \\ The Mining-Geology-Petroleum Engineering Bulletin UDC: 621.7 \\ DOI: 10.17794/rgn.2018.4.8 \\ Preliminary communication

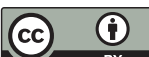

\author{
Masoud Akhyani ${ }^{1}$, Farhang Sereshki ${ }^{2}$, Reza Mikaeil ${ }^{*}$ \\ ${ }^{I}$ Department of Engineering, Shahrood Branch, Islamic Azad University, Shahrood, Iran. \\ ${ }^{2}$ Faculty of Mining, Petroleum and Geophysics, Shahrood University of Technology, Shahrood, Iran. \\ ${ }^{3}$ Department of Mining and Metallurgical Engineering, Urmia University of Technology, Urmia, Iran.
}

\begin{abstract}
The circular diamond saw (CDS) is one of the major sawing machines in dimension stone processing plants. Predicting the performance of a circular diamond saw is very important to estimate the cost and the planning of the stone processing plants. The performance of a CDS depends on some important factors such as machine and tool characteristics, physical and mechanical characteristics of rock and tool wear rate. In this research, it is aimed to investigate the relationship between ampere consumption, brittleness indexes and toughness with the wear rate of a CDS. This aim was pursued by using a fully instrumented cutting rig to cut 14 types of hard rock at constant feed rates, cut depths and peripheral speeds. Wear rate, toughness and brittleness indexes were evaluated using simple and multiple curvilinear regression analysis and predicted models were developed. The results indicated that there is a significant correlation between wear rate, ampere consumption and toughness. It is concluded that, the wear rate of a CDS can be reliably estimated using a multiple curvilinear model which includes ampere consumption and toughness.
\end{abstract}

Keywords:

Dimensional stone, Circular diamond saw, Brittleness index, Toughness, Statistical analysis.

\section{Introduction}

The prediction of dimension stone sawability is one of the most important factors in estimating the production cost and planning of the quarries and factories. Dimension stone sawability with a CDS dependent on parameters including; the rock and machine characteristics and saw operating characteristics. The investigation of these parameters in the stone industry is important for establishing the most suitable and economic usage of the sawing method in the future. Many studies have been done on the relations between a circular diamond saw (CDS) and stone characteristics such as in the relevant literature (Tonshoff et al. 2002; Konstanty 2002; Ilio and Togna 2003; Eyuboglo et al. 2003; Ersoy and Atici 2004; Ersoy et al. 2005; Fener et al. 2007; Guney 2011; Brook 2012; Aydin et al. 2013; Aydin et al. 2015, Tumac, 2015; Mikaeil et al. 2016). Up to now, the studies carried out in sawability and sawing characteristics in saw operating characteristics and sawing the design in stone processing (Wei et al. 2003; Kahraman et al. 2004; Gunaydin et al. 2004; Delgado et al. 2005; Kahraman et al. 2005; Buyuksagis 2007; Tutmez et al. 2007; Mikaeil et al. 2011a; Ataei et al. 2012; Mikaeil

Corresponding author: Reza Mikaeil

Reza.mikaeil@gmail.com et al. 2013; Mikaeil et al. 2015). In the others, the ampere consumption, vibration, the loads acting on the abrasive grits and brittleness indexes in cutting process are investigated (Xu et al. 2002; Xu et al. 2003; Aslantas et al. 2009; Atici and Ersoy 2009; Mikaeil et al. 2011b; Mikaeil et al. 2011c; Mikaeil et al. 2012; Yurdakul and Akdas 2012; Engin et al. 2013; Sengun and Altindag 2013; Karakurt 2014a; Karakurt 2014b; Mikaeil et al. 2014; Aryanfar and Mikaeil 2016).

The main goal of this research is to study the possibility of estimating the wear rate of a circular diamond saw from brittleness indexes and toughness in hard rock cutting process. First of all, the wear rate of a CDS was correlated with brittleness indexes and toughness using simple regression and then, multiple regression analysis was performed.

\section{Toughness}

Toughness refers to a material's ability to deform plastically and thus absorb the applied energy. To measure this property, a sample of the material must be subjected to a static test to acquire its characteristic stressstrain curve. The work done to fracture the sample can then be obtained by measuring the area under this curve. The volume-specific toughness is known as modulus of 
toughness and refers to the maximum work done (in inch-pounds) to rupture a unit volume (in cubic inch) of the material. For materials like cast iron and concrete, which have a parabolic shaped stress-strain curve, an accurate estimate of modulus of toughness, Mt, is given by Equation 1:

$$
M_{t}=\frac{2}{3} \times \sigma_{a} \times \varepsilon_{f}
$$

Where, $\sigma_{\mathrm{a}}$ is the ultimate strength and $\varepsilon_{\mathrm{f}}$ is the strain at failure (Deer and Miller 1966).

Tough materials have high strength and ductility while brittle materials have a generally low toughness due to their inability to absorb energy by undergoing plastic deformation (Jastrzebski 1959). The toughness of a material or rock is in fact the ability of its matrix to bind its constituent minerals and grains together but also depends on the strength of individual grains or minerals (Deer and Miller 1966). Thus, rocks with a strong matrix consisting of strong minerals are expected to be the toughest (Shepherd 1951). From a microscale point of view, it is the type and strength of binding forces between atoms, ions, or molecules that decide the hardness and toughness of a material. From a macroscale perspective, both hardness and toughness are closely correlated with the yield strength (Jastrzcbski 1959). One of the earliest toughness classification systems was introduced in 1926 by Harley. In this system, toughness was expressed as the ft-lbs. of work that must be done to drill one cubic inch of rock, and was related to a grinding resistance that could be determined using a small grinding machine.

\section{Brittleness indexes}

Another important mechanical property of rocks is brittleness, which has been generally defined as the property of materials that rupture or fracture without any measurable plastic deformation (Glossary of Geology and Related Sciences 1960). However, alternative definitions of brittleness have also been introduced by researchers of different backgrounds for different applications (Yarali and Soyer 2011). The notable definitions of brittleness are the lack of ductility (Hetenyi 1966), the deficiency in internal cohesion leading to an easy fracture (Ramsey 1967), and the property of materials such as cast iron and many rocks that fracture at or only slightly beyond the yield stress (Obert and Duvall 1967). As mentioned, brittleness can be described as a property of materials that rupture or fracture without undergoing measurable if any plastic deformation. The related literature contains a number of stress-strain curve based definitions for brittleness index (Baron 1962; Coates and Parsons 1966; Aubertin and Gill 1988; Aubertin et al. 1994; Ribacchi 2000; Hajiabdolmajid and Kaiser 2003). The present study uses the following definitions available for this index according to Equations 2 to 5 .

$$
\begin{gathered}
B_{1}=\frac{\sigma_{c}}{\sigma_{t}} \\
B_{2}=\frac{\sigma_{c}-\sigma_{t}}{\sigma_{t}+\sigma_{c}} \\
B_{3}=\frac{\sigma_{c} \times \sigma_{t}}{2} \\
B_{4}=\left(\sigma_{c} \times \sigma_{t}\right)^{0.72}
\end{gathered}
$$

Where, B1, B2, B3 and B4 are brittleness, $\sigma_{c}$ is the uniaxial compressive strength $(\mathrm{MPa}), \sigma_{t}$ is the Brazilian tensile strength (Mpa).

\section{Methodology of study}

In this study, the relationship of wear rate of a CDS with ampere consumption, brittleness indexes and toughness is investigated. This goal is pursued by using a fully instrumented cutting rig with a maximum spindle motor power of $4 \mathrm{~kW}$ and spindle speed of $3000 \mathrm{rpm}$ to cut 14 types of hard rock at constant feed rates, cut depths and peripheral speeds, and measuring the uniaxial compressive strength (UCS), Brazilian tensile strength (BTS), and Young's modulus (YM) as suggested by (ISRM 1981). To determine the UCS, the five standard NX core samples (length to diameter ratio of 2.5:1) were taken using a diamond rotating drill from a block sample. The mechanical tests were carried out by a servo controlled testing machine designed for rock test. The standard uniaxial compressive strength test of core samples was carried out under a loading rate of $1 \mathrm{Mpa} / \mathrm{s}$. The tangent Young's modulus at a stress level equal to $50 \%$ of the ultimate UCS is used in this study.

The circular diamond saw used in this study was 250 $\mathrm{mm}$ in diameter and had a $50 \mathrm{~mm}$ thick steel core with a standard narrow radial slot and 18 pieces of $35 \mathrm{~mm} \times 2.5$ $\mathrm{mm} \times 6.0 \mathrm{~mm}$ diamond impregnated segments fixed around its periphery, giving a grit size of about 50/60 US mesh at 35 percent concentration. In the course of this study, fourteen rock specimens were cut by the described saw. In the cutting process for each sample, the length of cutting was $120 \mathrm{~cm}$ in three steps and the cutting time was 60 seconds at each cutting step.

During the cutting test, ampere consumption was monitored by ampere meter. A digital ampere meter installed on the cutting machine was used to measure ampere consumption. For each sample, the average electrical current consumption was calculated in terms of ampere. The wear rate of the circular diamond saw was determined based on one segment. The measurement was taken for a selected segment, at the beginning and 
Table 1. The mechanical test results and the characteristics of studied rocks

\begin{tabular}{|l|l|l|l|l|l|l|l|l|l|l|l|}
\hline $\begin{array}{l}\text { Sample } \\
\text { Number }\end{array}$ & Name of granite rock & $\begin{array}{l}\text { UCS } \\
(\mathrm{MPa})\end{array}$ & $\begin{array}{l}\mathrm{BTS} \\
(\mathrm{MPa})\end{array}$ & $\begin{array}{l}\text { YM } \\
(\mathrm{GPa})\end{array}$ & $\begin{array}{l}\mathrm{T} \\
(\mathrm{MPa})\end{array}$ & $\mathrm{B} 1$ & $\mathrm{~B} 2$ & $\mathrm{~B} 3$ & $\mathrm{~B} 4$ & $\begin{array}{l}\mathrm{I} \\
(\mathrm{A})\end{array}$ & $\begin{array}{l}\text { Wr } \\
(\mathrm{mm} 3)\end{array}$ \\
\hline 1 & Gray Astan & 141 & 10.15 & 41.5 & 31.94 & 13.89 & 0.87 & 715.58 & 187.11 & 15.9 & $8.0 \mathrm{E}-07$ \\
\hline 2 & Blue Nehbandan & 155 & 13.1 & 39 & 41.07 & 11.83 & 0.84 & 1015.25 & 240.7 & 15.7 & $8.0 \mathrm{E}-07$ \\
\hline 3 & White Natanz & 150 & 11.28 & 43 & 34.88 & 13.3 & 0.86 & 846 & 211.08 & 16 & $2.5 \mathrm{E}-06$ \\
\hline 4 & Red Yazd & 142 & 8.52 & 44 & 30.55 & 16.67 & 0.89 & 604.92 & 165.79 & 16 & $1.6 \mathrm{E}-06$ \\
\hline 5 & Morvarid Mashad & 125 & 7.4 & 31 & 33.6 & 16.89 & 0.89 & 462.5 & 136.65 & 15.5 & $8.0 \mathrm{E}-07$ \\
\hline 6 & Khoramdareh & 133 & 8.3 & 29 & 40.66 & 16.02 & 0.88 & 551.95 & 155.21 & 15.4 & $6.0 \mathrm{E}-07$ \\
\hline 7 & Ceram Nehbandan & 145 & 9.2 & 36 & 38.94 & 15.76 & 0.88 & 667 & 177.87 & 15.9 & $6.0 \mathrm{E}-07$ \\
\hline 8 & Black Natanz & 157 & 15.46 & 37 & 44.41 & 10.16 & 0.82 & 1213.61 & 273.70 & 16.5 & $4.5 \mathrm{E}-06$ \\
\hline 9 & Astan nehbandan & 138 & 8.15 & 29 & 43.78 & 16.93 & 0.89 & 562.35 & 157.31 & 15.2 & $1.1 \mathrm{E}-06$ \\
\hline 10 & Black Alamot & 173 & 15.98 & 46 & 43.38 & 10.83 & 0.83 & 1382.27 & 300.59 & 16.1 & $9.2 \mathrm{E}-07$ \\
\hline 11 & Black Hamedan & 185 & 17 & 49 & 46.56 & 10.88 & 0.83 & 1572.5 & 329.83 & 16.5 & $1.5 \mathrm{E}-06$ \\
\hline 12 & Jangali Birjand & 239 & 18.86 & 52 & 73.23 & 12.67 & 0.85 & 2253.77 & 427.40 & 17 & $6.4 \mathrm{E}-06$ \\
\hline 13 & Green Yazd & 199 & 16.14 & 49.5 & 53.33 & 12.33 & 0.85 & 1605.93 & 334.86 & 16.6 & $2.5 \mathrm{E}-06$ \\
\hline 14 & Black Chayan & 173 & 15 & 49 & 40.72 & 11.53 & 0.84 & 1297.5 & 287.2 & 15.8 & $2.2 \mathrm{E}-06$ \\
\hline
\end{tabular}

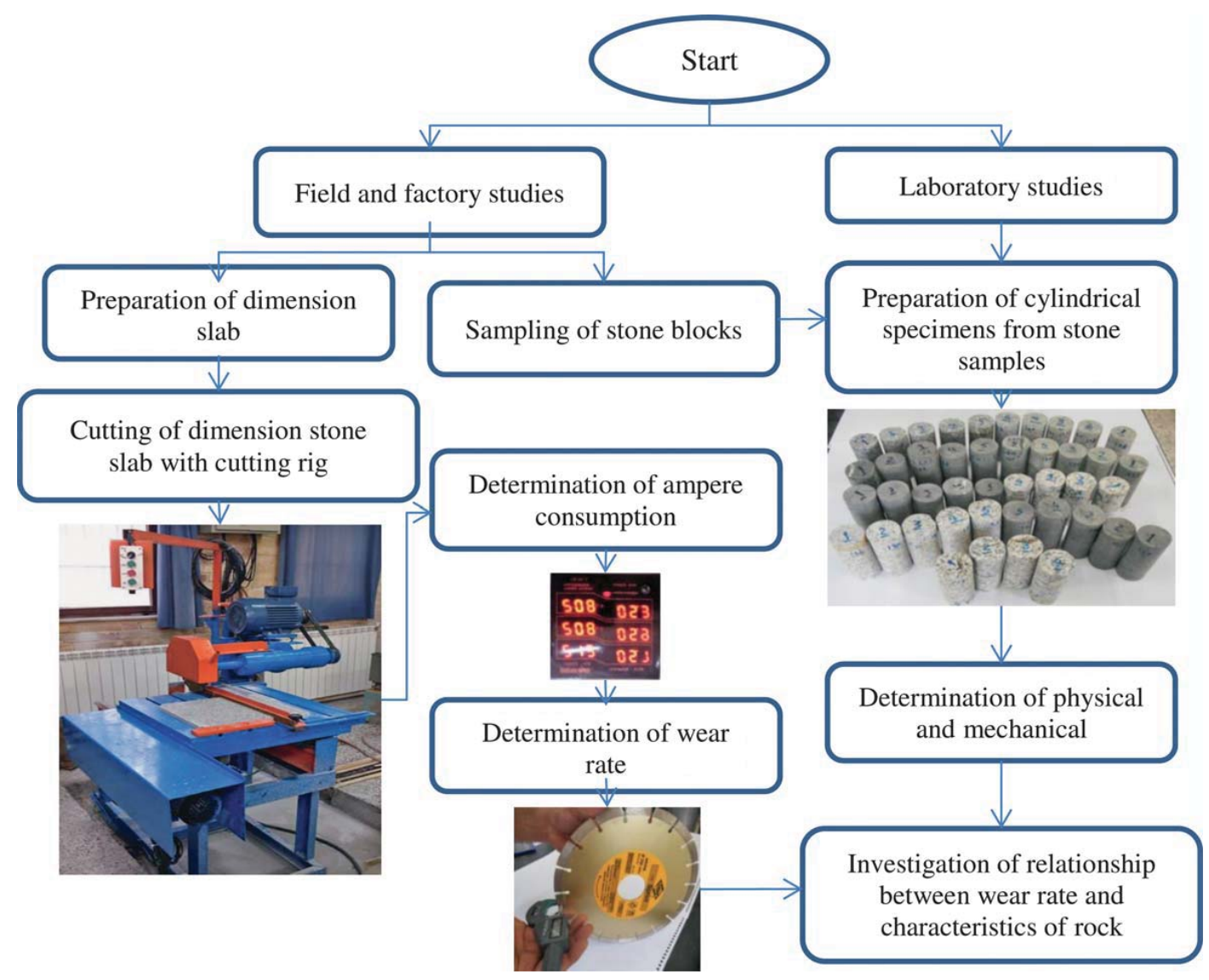

Figure 1: Flowchart of study

end of each cutting test. Changes of segment height, width and length of the circular diamond saw were measured for determination of the wear rate by a digital micrometer (resolution of $0.001 \mathrm{~mm}$ ). During the sawing trials, the cutting operating parameters such as periph- eral speed $(3000 \mathrm{rpm})$, feed rate $(0.67 \mathrm{~cm} / \mathrm{s})$, and depth of cut $(0.5 \mathrm{~cm})$ were considered constant. The results of laboratory study are given in Table $\mathbf{1}$.

Wear rate, ampere consumption, toughness and brittleness indexes were evaluated using simple and multi- 
ple curvilinear regression analysis and predicted models were developed. The flowchart of this study is illustrated in Figure 1.

\section{Statistical analysis}

\subsection{Simple regression}

In this statistical analysis, the wear rate of the circular diamond saw, toughness and brittleness indexes were correlated by the least squares regression method. We tested the linear, logarithmic, exponential and power regressions and determined, for each regression, the approximation equation that yields the highest correlation coefficient. The wear rate versus type of brittleness are

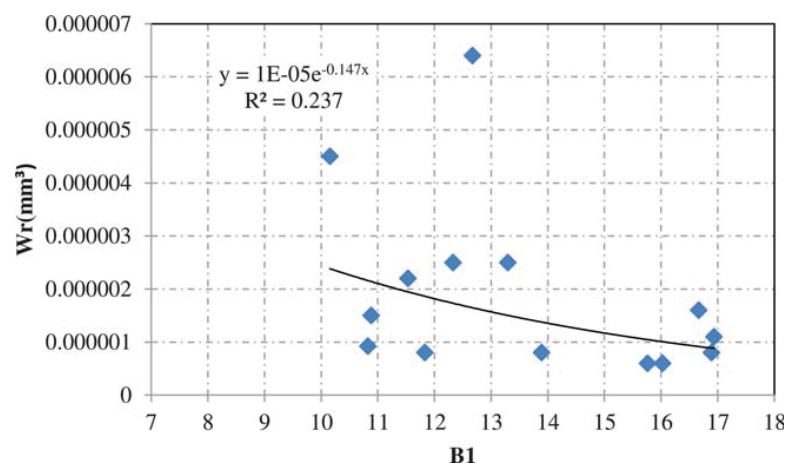

Figure 2: Wear rate versus $B_{1}$

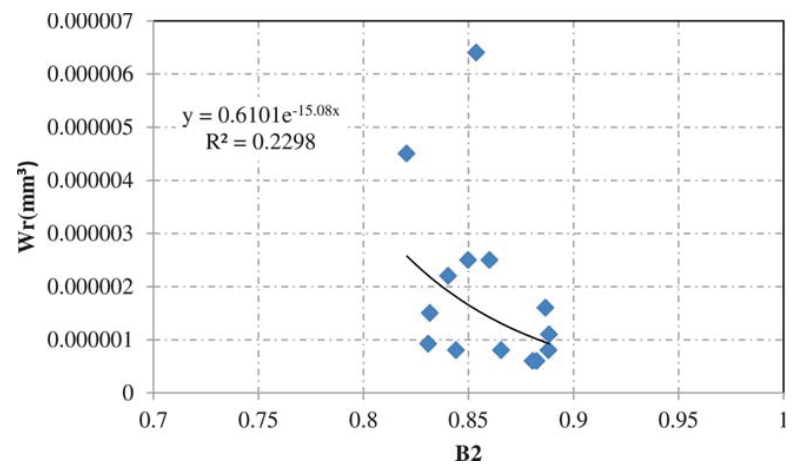

Figure 3: Wear rate versus B2

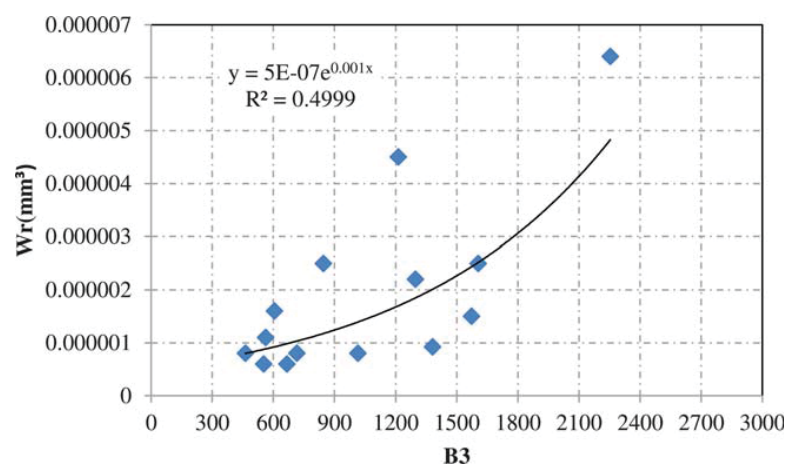

Figure 4: Wear rate versus $B_{3}$

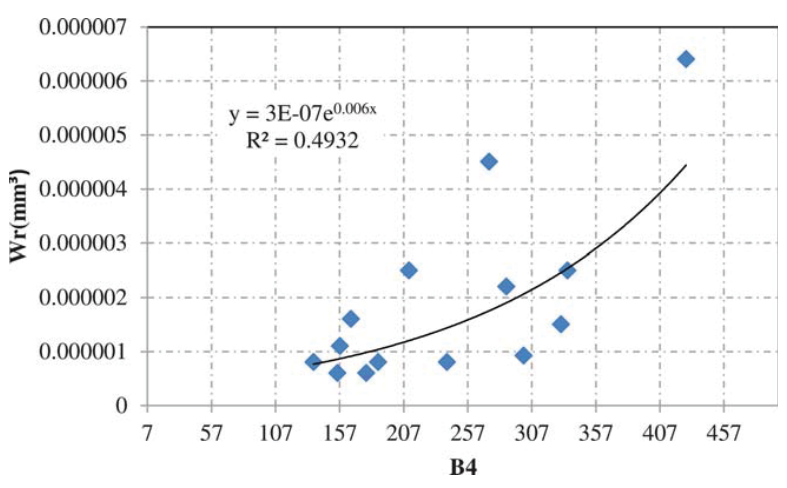

Figure 5: Wear rate versus $\mathrm{B}_{4}$

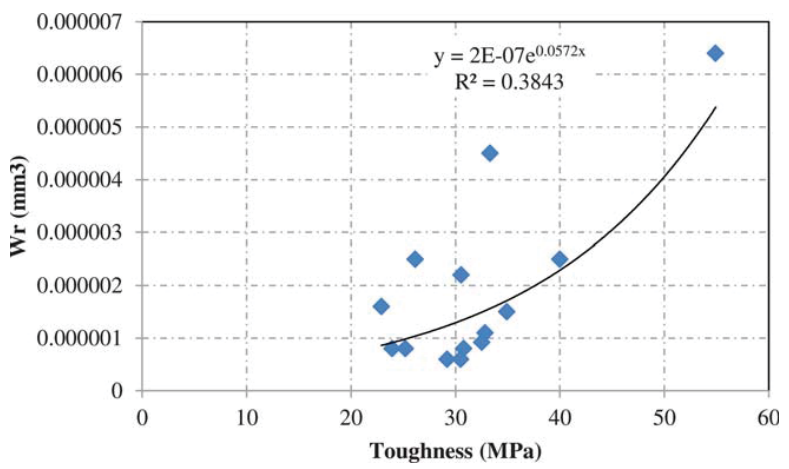

Figure 6: Wear rate versus toughness

shown in Figures 2 to 5 . Figure 6 shows the relationship between the wear rate and toughness. Equations 6 to 9 express the relationship between the wear rate and type of brittleness, and Equation 10 expresses dependence of wear rate on toughness. These equations are presented by Equations 6 to 10:

$$
\begin{gathered}
W_{r}=10^{-5} \times \operatorname{EXP}\left(-0.147 B_{1}\right) \\
W_{r}=0.6101 \times \operatorname{EXP}\left(-15.08 B_{2}\right) \\
W_{r}=5 \times 10^{-7} \times \operatorname{EXP}\left(0.001 B_{3}\right) \\
W_{r}=3 \times 10^{-7} \times \operatorname{EXP}\left(0.006 B_{4}\right) \\
W_{r}=2 \times 10^{-7} \times \operatorname{EXP}(0.0429 T)
\end{gathered}
$$

Where $\mathrm{Wr}$ is the wear rate of the diamond saw, $\mathrm{mm} 3$, B1, B2, B3 and B4 are brittleness indexes.

\subsection{Multiple curvilinear regression analysis}

In this section, the wear rate of the diamond saw at different brittleness indexes, toughness and ampere consumption were analysed using multiple curvilinear regression. Regression analysis was performed by the computing software "Statistical Package for the Social Sciences (SPSS)". The regression models including two independent variables are presented in Equations 11 to 15: 


$$
\begin{aligned}
& W_{r}=\frac{I^{17.35}}{B_{1}^{0.121} \times 10^{26.59}} \\
& W_{r}=\frac{I^{17.25}}{B_{2}^{1.01} \times 10^{26.68}} \\
& W_{r}=\frac{I^{14.17} \times B_{3}^{0.275}}{10^{23.72}} \\
& W_{r}=\frac{I^{14.17} \times B_{4}^{0.382}}{10^{23.8}} \\
& W_{r}=\frac{I^{15.01} \times T^{0.619}}{10^{24.92}}
\end{aligned}
$$

Where I is ampere consumption, A.

Equations 11 to 15 were derived from B1, B2, B3, $\mathrm{B} 4$, toughness and I. the wear rate of the circular diamond saw increases with an increase in the ampere consumption. The ampere consumption is easy to detect during the sawing process, so it can be used in the stone processing plants to predict the wear rate in different sawing conditions.

\subsection{Validation of models}

Validation of the developed models was performed while considering the $\mathrm{F}$ test, the $\mathrm{t}$ test, correlation coefficient $\left(\mathrm{R}^{2}\right)$, and the plots of predicted values versus the actual values. The statistical results of the five models are given in Table 2.

The $\mathrm{R}^{2}$ of Equations $\mathbf{1 1}$ to $\mathbf{1 5}$ are 0.56, 0.56, 0.57, 0.57 , and 0.58 , respectively. These values are fair, however, they show better values in comparison with Equations 6 to 10. The $t$ test was used to determine the sig- nificance of $\mathrm{R}^{2}$. For the use of this test, the tabulated $\mathrm{t}$ value ( $\left.t^{*}\right)$ according to the confidence level is compared with the computed $t$ value to accept or reject the null hypothesis. A computed $t$ value that is greater than the tabulated $t$ value disproves the null hypothesis; in this case, $\mathrm{R}^{2}$ is important. Otherwise, the null hypothesis is not rejected, and $\mathrm{R}^{2}$ is not significant. With a $90 \%$ confidence level, the tabulated $t$ value \pm 1.363 for equations

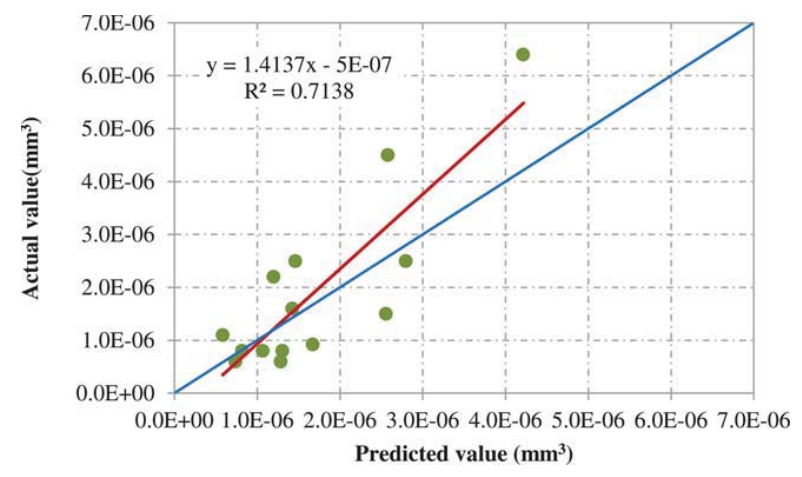

Figure 7: Predicted wear rate versus actual wear rate for Eq. (11)

\begin{tabular}{|c|c|c|c|c|c|c|c|c|}
\hline Model & Independent variables & Coefficients & Std. Error & $\mathrm{t}$ & $t^{*}$ & $\mathrm{~F}$ & $\mathrm{~F}^{*}$ & $\mathrm{R}^{2}$ \\
\hline \multirow[t]{3}{*}{ Eq. (11) } & Constant & -26.59 & 8.11 & -3.277 & \multirow{3}{*}{ \pm 1.36} & \multirow{3}{*}{6.99} & \multirow{3}{*}{ \pm 4.75} & \multirow{3}{*}{0.56} \\
\hline & I & 17.35 & 6.09 & 2.85 & & & & \\
\hline & $\mathrm{B}_{1}$ & -0.121 & 1.05 & -0.12 & & & & \\
\hline \multirow[t]{3}{*}{ Eq. (12) } & Constant & -26.68 & 6.96 & -3.83 & \multirow{3}{*}{ \pm 1.36} & \multirow{3}{*}{6.99} & \multirow{3}{*}{ \pm 4.75} & \multirow{3}{*}{0.56} \\
\hline & I & 17.25 & 5.99 & 2.88 & & & & \\
\hline & $\mathrm{B}_{2}$ & -1.01 & 6.8 & -0.148 & & & & \\
\hline \multirow[t]{3}{*}{ Eq. (13) } & Constant & -23.72 & 9.154 & -2.591 & \multirow{3}{*}{ \pm 1.36} & \multirow{3}{*}{7.24} & \multirow{3}{*}{ \pm 4.75} & \multirow{3}{*}{0.57} \\
\hline & I & 14.17 & 8.727 & 1.624 & & & & \\
\hline & $\mathrm{B}_{3}$ & 0.275 & 0.559 & 0.492 & & & & \\
\hline \multirow[t]{3}{*}{ Eq. (14) } & Constant & -23.8 & 9.023 & -2.638 & \multirow{3}{*}{ \pm 1.36} & \multirow{3}{*}{7.24} & \multirow{3}{*}{ \pm 4.75} & \multirow{3}{*}{0.57} \\
\hline & I & 14.17 & 8.727 & 1.624 & & & & \\
\hline & $\mathrm{B}_{4}$ & 0.382 & 0.773 & 0.492 & & & & \\
\hline \multirow[t]{3}{*}{ Eq. (15) } & Constant & -24.92 & 6.42 & -3.88 & \multirow{3}{*}{ \pm 1.36} & \multirow{3}{*}{7.59} & \multirow{3}{*}{ \pm 4.75} & \multirow{3}{*}{0.58} \\
\hline & I & 15.01 & 5.96 & 2.52 & & & & \\
\hline & $\mathrm{T}$ & 0.619 & 0.83 & 0.744 & & & & \\
\hline
\end{tabular}

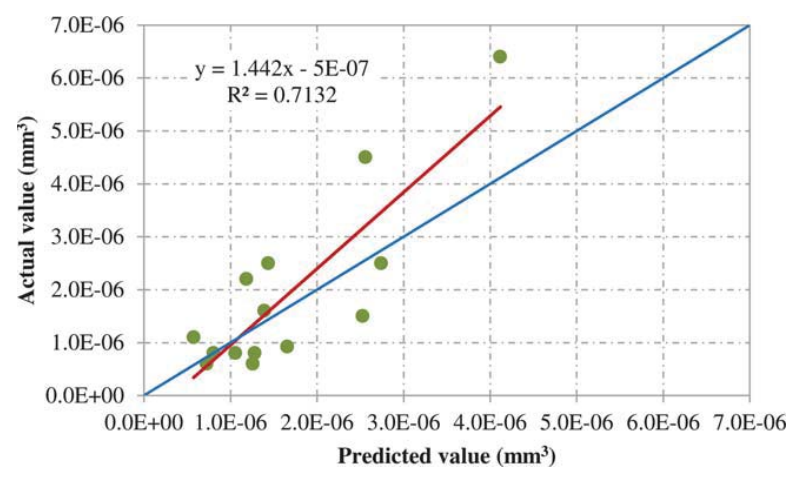

Figure 8: Predicted wear rate versus actual wear rate for Eq. (12)

Table 2. Statistical results of the multiple regression models 


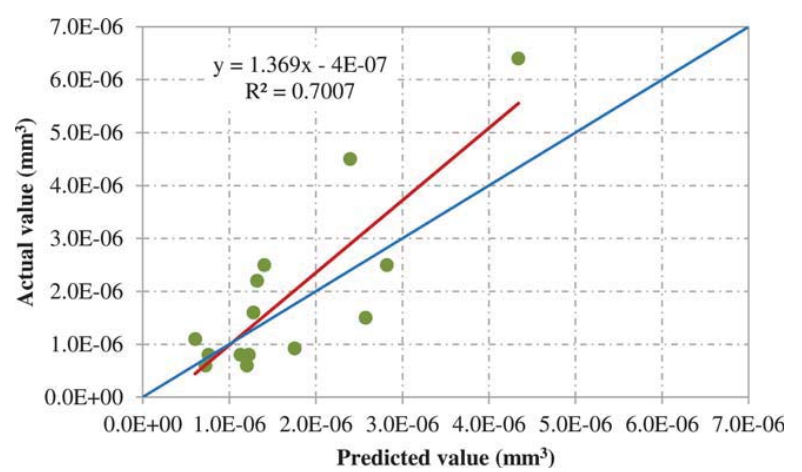

Figure 9: Predicted wear rate versus actual wear rate for Eq. (13)

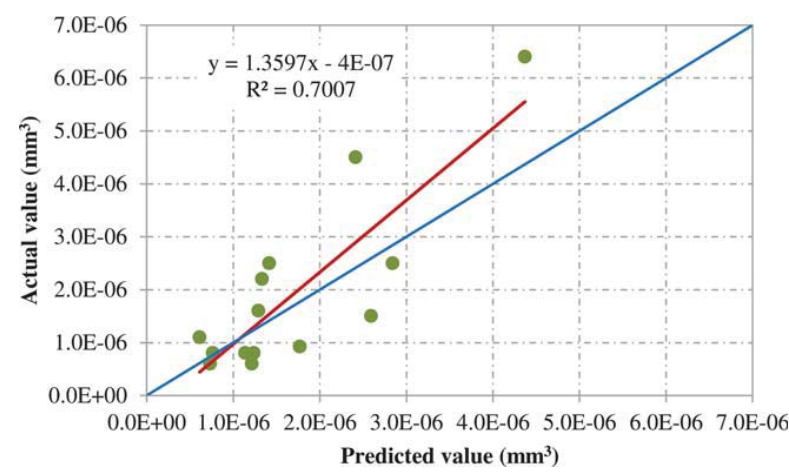

Figure 10: Predicted wear rate versus actual wear rate for Eq. (14)

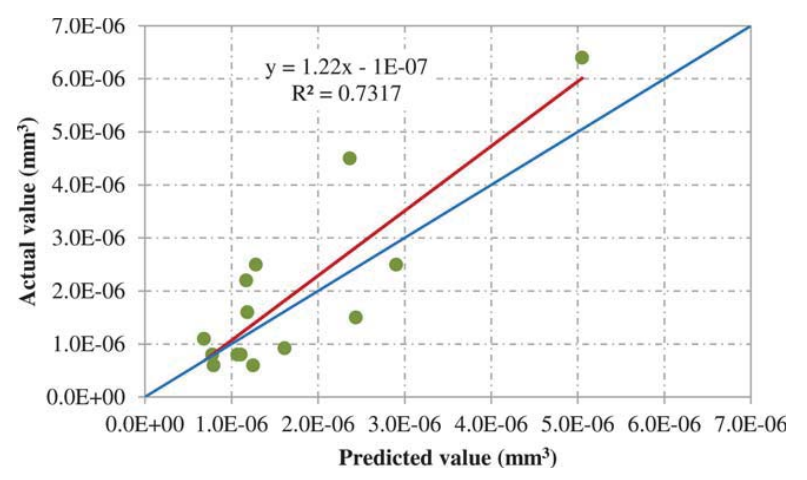

Figure 11: Predicted wear rate versus actual wear rate for Eq. (15)

was found. According to Table 2, the computed t values are greater than the tabulated $t$ value. However, some computed t values for equations are lower than tabulated $\mathrm{t}$ values. This means there is some doubt for these models. Among these models, only Eq. 15 is valid with a $75 \%$ confidence level. Analysis of variance was done to test the significance of regressions with the $\mathrm{F}$ test. In this study, a 95\% level of confidence was selected. The computed $F$ values are greater than the tabulated $F$ values $\left(\mathrm{F}^{*}\right)$, therefore, the null hypothesis is rejected and the models are valid. The scatter diagrams of the actual and predicted values were used to see the prediction capabil- ity of the developed models. The scatter diagram of predicted versus actual values for the equations are shown in Figures 7 to 11, respectively. As can be seen in these Figs, a systematic deviation from the 1:1 diagonal straight line is low for Equation 15 in comparison with the other equations.

\section{Conclusion}

The circular diamond saw is one of the most important machines used in stone processing plants. The performance prediction of these saws is important in the cost estimation and the planning of the plants. An accurate estimation of wear rate helps to make the planning of the rock sawing programs more effectual. In this study, the relationship between wear rate of a circular diamond saw, toughness, and brittleness indexes of hard rocks were investigated using simple and multiple curvilinear regression analysis. According to the results of simple regression analysis, B3, B4, and toughness indexes show a better correlation with the wear rate. For practical considerations, ampere consumption was measured during the sawing process. Some models were obtained using multiple curvilinear regression with respect to ampere consumption, toughness, and brittleness indexes. Finally, validation of the developed models were analysed while considering the $\mathrm{F}$ test, the $\mathrm{t}$ test, correlation coefficient, and the plots of predicted values versus actual values and the best model was selected. The results showed that the wear rate of a CDS can reliably be predicted from ampere consumption and toughness. It is important to emphasize, the developed model can be applied only on granite rocks. More research must be done to check the validity of the obtained model for other types of rocks and the effect of the type of saw.

\section{References}

Aryafar, A. and Mikaril, R. (2016): Estimation of the Ampere Consumption of Dimension Stone Sawing Machine Using of Artificial Neural Networks. Int. Journal of Mining \& Geo-Engineering 50, 1, 121-130. doi:..10.22059/ijmge.2016.57861.

Aslantas, K., Özbek, O. and Ucun, I. (2009): Investigation of the Effect of Axial Cutting Force on Circular Diamond Sawblade Used in Marble Cutting Process. Materials and Manufacturing Processes, 24, 12, 1423-1430. doi: org/10.1080/10426910903344039.

Ataei, M., Mikaeil, R., Hoseinie, S.H. and Hosseini, S.M. (2012): Fuzzy analytical hierarchy process approach for ranking the sawability of carbonate rock. International Journal of Rock Mechanics and Mining Sciences, 50, 8393....doi.org/10.1016/j.ijrmms.2011.12.002.

Atici, U. and Ersoy, A. (2009): Correlation of specific energy of cutting saws and drilling bits with rock brittleness and destruction energy. journal of materials processing technology, 209, 5, 2602-2612....doi.org/10.1016/j.jmatprotec.2008.06.004. 
Aubertin, M. and Gill, D.E. (1988): A methodology for assessing the potential for rock bursts in Abitibi mine. In Proceedings of Colloque sur le Controle de Terrain (AMMQ), Val d'Or, 47-77.

Aubertin, M., Gill, D.E. and Simon, R. (1994): On the use of the brittleness index modified (BIM) to estimate the postpeak behavior of rocks. 1st North American Rock Mechanics Symposium. American Rock Mechanics Association.

Aydin, G., Karakurt, I. and Aydiner, K. (2013): Wear performance of saw blades in processing of granitic rocks and development of models for wear estimation. Rock mechanics and rock engineering, 46, 6, 1559-1575. doi: 10.1007/s00603-013-0382-y.

Aydin, G., Karakurt, I. and Hamzacebi, C. (2015): Performance prediction of diamond sawblades using artificial neural network and regression analysis. Arabian Journal for Science and Engineering, 40, 7, 2003-2012. doi: 10.1007/s13369-015-1589-x. doi: 10.1007/s13369-0151589-x.

Baron, L.I., Loguntsov, B.M. and Posin, E.Z. (1962): Determination of properties of rocks. Gosgortekhizdat, Moscow.

Brook, B. 2002. Principles of diamond tool technology for sawing rock. International Journal of Rock Mechanics and Mining Sciences, 39, 1, 41-58..-\%\%-doi.org/10.1016/ S1365-1609(02)00007-2.

Buyuksagis, I.S. (2007): Effect of cutting mode on the sawability of granites using segmented circular diamond sawblade. Journal of Materials Processing Technology, 183, 2, 399-406....doi.org/10.1016/j.jmatprotec.2006.10.034.

Coates, D.F. and Parsons, R.C. (1966): Experimental criteria for classification of rock substances. In International Journal of Rock Mechanics and Mining Sciences \& Geomechanics Abstracts, 3, 3, 181-189../-\%\%-doi.org/ 10.1016/0148-9062(66)90022-2.

Deere, D.U. and Miller, R.P. (1966): Engineering classification and index properties for intact rock. ILLINOIS UNIV AT URBANA DEPT OF CIVIL ENGINEERING.

Delgado, N.S., Rodríguez-Rey, A., del Río, L.M Suárez., Díez Sarriá, I., Calleja, L. and Argandona, V.G.R. (2005): The influence of rock microhardness on the sawability of Pink Porrino granite (Spain). International journal of rock mechanics and mining sciences, 42, 1, 161-166. doi: 10.1016/ j.ijrmms.2004.08.010.

Engin, I.C., Bayram, F. and Yasitli, N.E. (2013): Experimental and statistical evaluation of cutting methods in relation to specific energy and rock properties. Rock mechanics and rock engineering, 46, 4, 755-766. doi: 10.1007/s00603012-0284-4

Ersoy, A. and Atici, U. (2004): Performance characteristics of circular diamond saws in cutting different types of rocks. Diamond and Related Materials, 13, 1, 22-37....doi. org/10.1016/j.diamond.2003.08.016.

Ersoy, A., Buyuksagic, S. and Atici, U. (2005): Wear characteristics of circular diamond saws in the cutting of different hard abrasive rocks. Wear, 258, 9, 1422-1436....doi. org/10.1016/j.wear.2004.09.060.

Eyuboglu, A.S., Ozcelik, Y., Kulaksiz, S. and Engin, I.C. (2003): Statistical and microscopic investigation of disc segment wear related to sawing Ankara andesites. International Journal of Rock Mechanics and Mining Sciences 40 (3), 405-414. doi:.\%-\%\%-10.1016/S1365-1609(03) 00002-9.

Fener, M., Kahraman, S. and Ozder, M.O. (2007): Performance prediction of circular diamond saws from mechanical rock properties in cutting carbonate rocks. Rock Mechanics and Rock Engineering, 40, 5, 505-517. doi: 10.1007/s00603-006-0110-y.

Glossary of Geology and Related Sciences, Amer. Geology. Inst. (1960): Washington D.C.

Gunaydin, O., Kahraman, S. and Fener, M. (2004): Sawability prediction of carbonate rocks from brittleness indexes. J South Afr Inst Min Metall, 104, 4, 239-44.

Güney, A. (2011): Performance prediction of large-diameter circular saws based on surface hardness tests for Mugla (Turkey) marbles. Rock Mechanics and Rock Engineering, 44, 3, 357-366. doi: 10.1007/s00603-010-0119-0.

Hajiabdolmajid, V. and Kaiser, P. (2003): Brittleness of rock and stability assessment in hard rock tunneling. Tunnelling and Underground Space Technology, 18, 1, 35-48..-\%\%doi.org/10.1016/S0886-7798(02)00100-1.

Harley, G.T. (1926): Proposed Ground Classification for Mining Purposes--I and II. Engineering and Mining journal. $122,10 \& 11,368 \& 413$.

Hetenyi, M. (1966): Beams and plates on elastic foundations and related problems. Appl. Mech. Rev, 19, 2, 95-102.

Ilio, A.D., Togna, A. (2003): A theoretical wear model for diamond tools in stone cutting. Int. J. Mach. Tools Manuf. 43, 1171-1177.

ISRM. (1981): Rock Characterization Testing and Monitoring Suggested Methods, Oxford. p. 16.

Jastrzebski, Z., D. (1959): Nature and Properties of Engineering Materials, John Wiley \& Sons, New York, 159 p.

Kahraman, S., Fener, M. and Gunaydin, O. (2004): Predicting the sawability of carbonate rocks using multiple curvilinear regression analysis. International journal of rock mechanics and mining sciences, 41, 7, 1123-1131....doi. org/10.1016/j.ijrmms.2004.04.009.

Kahraman, S., Altun, H., Tezekici, B.S. and Fener, M. (2006): Sawability prediction of carbonate rocks from shear strength parameters using artificial neural networks. International Journal of Rock Mechanics and Mining Sciences, 43, 1, 157-164. doi:10.1016/j.ijrmms.2005.04.007.

Karakurt, I. (2014a): Specific energy optimization in sawing of rocks using Taguchi approach. Journal of Central South University, 21, 1, 365-372.

Karakurt, I. (2014b): Application of Taguchi method for cutting force optimization in rock sawing by circular diamond sawblades. Sadhana, 39, 5, 1055-1070. doi: 10.1007/ s12046-014-0279-9.

Konstanty, J. (2002): Theoretical analysis of stone sawing with diamonds. Journal of materials processing technology. $123,1,146-154 . .-\% \%$-doi.org/10.1016/S0924-0136 (02)00071-7.

Mikaeil, R., Yousefi, R. and Ataei, M. (2011a): Sawability ranking of carbonate rock using fuzzy analytical hierarchy process and TOPSIS approaches. Scientia Iranica, 18, 5, 1106-1115....doi.org/10.1016/j.scient.2011.09.009. 
Mikaeil, R., Ozcelik, Y., Ataei, M. and Yousefi, R. (2011b): Correlation of specific ampere draw with rock brittleness indexes in rock sawing process. Archives of Mining Sciences, 56, 4, 777-788.

Mikaeil, R., Ataei, M., and Yousefi R. (2011c): Application of a fuzzy analytical hierarchy process to the prediction of vibration during rock sawing. Mining Science and Technology (China), 21, 5, 611-619....doi.org/10.1016/j. mstc.2011.03.008.

Mikaeil R., Ataei M. and Yousefi, R. (2012): Evaluating the Power Consumption in Carbonate Rock Sawing Process by Using FDAHP and TOPSIS Techniques. Efficient Decision Support Systems: Practice and Challenges From Current to Future / Book 2. ISBN 978-953-307-441$2,478$.

Mikaeil, R., Ozcelik, Y., Yousefi, R., Ataei, M. and Hosseini, S.M. (2013): Ranking the sawability of ornamental stone using Fuzzy Delphi and multi-criteria decision-making techniques. International Journal of Rock Mechanics and Mining Sciences, 58, 118-126....doi.org/10.1016/j. ijrmms.2012.09.002.

Mikaeil, R., Ataei, M., Ghadernejad S. and Sadegheslam, G. (2014): Predicting the Relationship between System Vibration with Rock Brittleness Indexes in Rock Sawing Process. Archives of Mining Sciences, 59, 1, 139-154. doi: 10.2478/amsc-2014-0010

Mikaeil, R., Abdollahi Kamran, M., Sadegheslam, G. and Ataei, M. (2015): Ranking sawability of dimension stone using PROMETHEE method. Journal of Mining and Environment, 6, 2, 263-271. doi:..10.22044/jme.2015.477.

Mikaeil, R., Shaffiee Haghshenas, S., Shaffiee Haghshenas, S. and Ataei, M. (2016): Performance prediction of circular saw machine using imperialist competitive algorithm and fuzzy clustering technique. Neural Computing and Applications, 1-10. doi: 10.1007/s00521-016-2557-4.

Obert, L. and Wilbur, I. D. (1967): Rock Mechanics and the Design of Structures in Rock. John Wiley \& Sons Inc; 1st edition, $650 \mathrm{p}$.

Ramsay, J.G. (1967): Folding and fracturing of rocks. McGraw-Hill Companies.

Ribacchi, R. (2000): Mechanical tests on pervasively jointed rock material: insight into rock mass behaviour. Rock mechanics and rock engineering, 33, 4, 243-266. doi: 10.1007/ s006030070002.
Sengun, N. and Altindag, R. (2013): Prediction of specific energy of carbonate rock in industrial stones cutting process. Arabian Journal of Geosciences, 6, 4, 1183-1190. doi: 10.1007/s12517-011-0429-x.

Shepherd, R. (1950): Physical properties and drillability of mine rocks. Colliery Engineering, 27, 468-470.

Tönshoff, H.K., Hillmann-Apmann, H. and Asche, J. (2002): Diamond tools in stone and civil engineering industry: cutting principles, wear and applications. Diamond and Related Materials, 11, 3, 736-741..-\%\%-doi :org/10.1016/ S0925-9635(01)00561-1.

Tumac, D. (2015): Predicting the performance of large diameter circular saws based on Schmidt hammer and other properties for some Turkish carbonate rocks. International Journal of Rock Mechanics and Mining Sciences, 75, 159168....doi.org/10.1016/j.ijrmms.2015.01.015.

Tutmez, B., Kahraman, S. and Gunaydin, O. (2007): Multifactorial fuzzy approach to the sawability classification of building stones. Construction and Building Materials, 21, 8, 1672-1679. doi.org/10.1016/j.conbuildmat.2006. 05.023 .

Wei, X., Wang, C.Y. and Zhou, Z.H. (2003): Study on the fuzzy ranking of granite sawability. Journal of Materials Processing Technology, 139, 1, 277-280. doi:.\%-\%\%-10. 1016/S0924-0136(03)00235-8.

Xu, X.P., Li, Y., Zeng, W.Y. and Li, L.B. (2002): Quantitative analysis of the loads acting on the abrasive grits in the diamond sawing of granites. Journal of materials processing technology, 129, 1, 50-55..-\%\%-doi.org/10.1016/S09240136(02)00574-5.

Xu, X., Li, Y. and Yu, Y. (2003): Force ratio in the circular sawing of granites with a diamond segmented blade. Journal of Materials Processing Technology, 139, 1, 281-285..$\% \%$ doi.org/10.1016/S0924-0136(03)00236-X.

Yarali, O. and Soyer, E. (2011): The effect of mechanical rock properties and brittleness on drillability. Scientific research and Essays, 6, 5, 1077-1088. doi: 10.5897/SRE10.1004.

Yurdakul, M. and Akdas, H. (2012): Prediction of specific cutting energy for large diameter circular saws during natural stone cutting. International Journal of Rock Mechanics and Mining Sciences, 53, 38-44. doi.org/10.1016/j.ijrmms. 2012.03.008. 